\title{
EDUKASI PENCEGAHAN STUNTING BAGI KELUARGA PENERIMA MANFAAT BANTUAN SOSIAL KAMPUNG POLAY KECAMATAN GAPURA
}

\author{
Enza Resdiana ${ }^{1}$, Laylatul Hasanah ${ }^{2}$ \\ ${ }^{1}$ Fakultas Ilmu Sosial dan Politik Universitas Wiraraja \\ ${ }^{2}$ Fakultas Ilmu Kesehatan Universitas Wiraraja \\ ${ }^{1}$ E-mail address enza@wiraraja.ac.id; \\ 2E-mail address laylatulhasanah@wiraraja.ac.id
}

\begin{abstract}
The success of the program to combat and reduce the number of stunting sufferers cannot be separated from the cooperation of all parties, as well as the support of all levels of society to promote stunting prevention. This reduction in the stunting rate also involves a conditional cash transfer program that provides a positive side in providing assistance and health services to Pregnant Women with Chronic Energy Deficiency (KEK), children under two years old and Toddlers. One of the government programs that is carried out continuously in reducing stunting rates in Indonesia is the conditional cash transfer program where the conditional cash transfer program is a social protection program that provides conditional cash assistance to beneficiary families who are required to carry out the terms and conditions that have been set. These requirements and conditions are contained in the Regulation of the Minister of Social Affairs which discusses the rights and obligations that must be carried out by the beneficiary. Health and nutrition campaigns and education for the community also need to be done, one of the things that can be done is to improve prevention and care services for children who have nutritional problems, special and sustainable handling needs to be done.
\end{abstract}

Keywords: Stunting, Policy, Education.

\begin{abstract}
Abstrak
Kesuksesan program memerangi dan menurunkan angka penderita stunting itu tidak lepas dari kerja sama semua pihak, serta dukungan segenap lapisan masyarakat untuk menggalakkan pencegahan stunting. Penurunan angka stunting ini juga melibatkan program bantuan tunai bersyaratyang memberikan sisi positif dalam memberikan pendampingan dan pelayanan kesehatan terhadap Ibu Hamil Kurang Energi Kronis (KEK), anak dibawah dua tahun dan Balita. Salah satu program pemerintah yang dilakukan secara berkelanjutan dalam mengurangi angka stunting di Indonesia yaitu
\end{abstract}


Program bantuan tunai bersyarat dimana Program bantuan tunai bersyarat sebagai program perlindungan sosial yang memberikan bantuan tunai bersyarat kepada keluarga penerima manfaat yang diwajibkan melaksanakan persyaratan dan ketentuan yang telah ditetapkan. Persyaratan dan ketentuan tersebut tertuang dalam Peraturan Menteri Sosial yang membahas tentang hak dan kewajiban yang harus dijalankan oleh penerima bantuan. Kampanye dan edukasi kesehatan dan gizi untuk masyarakat pun perlu untuk dilakukan salah satu hal yang dapat dilakukan yaitu meningkatkan layanan pencegahan dan perawatan untuk anak-anak yang mengalami masalah gizi perlu dilakukan penanganan khusus dan berkelanjutan.

Kata kunci : Stunting, Kebijakan, Edukasi.

\section{PENDAHULUAN}

Data termutakhir dari hasil riset studi status gizi balita Indonesia (SSGBI) 2019 mencatat bahwa jumlah balita stunting di Indonesia saat ini mencapai 27,67 persen. Artinya, terdapat 6.3 juta dari populasi 23 juta balita di Indonesia yang mengidap masalah stunting. Jumlah yang telah melampaui nilai standar maksimal dari Organisasi Kesehatan Dunia (WHO) yakni sebesar 20 persen atau seperlima dari jumlah total anak balita dalam suatu negara. Pemerintah sendiri telah menyiapkan 5 strategi dalam menurunkan dan mencegah stunting. Targetnya adalah pada 2024 stunting turun menjadi $14 \%$, salah satunya melalui prioritas penanganan stunting yang dilakukan terhadap $260 \mathrm{kab} /$ kota. Selain itu, kampanye dan edukasi kesehatan dan gizi untuk masyarakat pun perlu untuk dilakukan salah satu hal yang dapat dilakukan yaitu meningkatkan layanan pencegahan dan perawatan untuk anakanak yang mengalami masalah gizi perlu dilakukan penanganan khusus dan berkelanjutan.

Salah satu program Pemerintah yang dilakukan secara berkelanjutan dalam mengurangi angka stunting di Indonesia yaitu Program bantuan tunai bersyaratdimana Program bantuan tunai bersyaratsebagai program perlindungan sosial yang memberikan bantuan tunai bersyarat kepada Keluarga Penerima Manfaat yang diwajibkan melaksanakan persyaratan dan ketentuan yang telah ditetapkan. Persyaratan dan ketentuan tersebut tertuang dalam Peraturan Menteri Sosial yang membahas tentang Hak dan kewajiban yang harus dijalankan oleh penerima bantuan.

Peraturan Menteri Sosial Nomor 1 Tahun 2018 tentang Program bantuan tunai bersyaratmenjelaskan bahwa dalam Program bantuan tunai bersyarat terdapat Hak dan Kewajiban yang dimiliki oleh Keluarga Penerima Manfaat, dimana hak dan kewajiban ini mengikat Keluarga 
Penerima Manfaat supaya berkomitmen selama menjadi penerima bantuan. Dalam Pasal 6 menyebutkan bahwa Hak yang dimiliki oleh Keluarga Penerima Manfaat program bantuan sosial tunai bersyarat yaitu bantuan sosial program bantuan sosial tunai bersyarat, pendampingan program bantuan sosial tunai bersyarat, Pelayanan difasilitas kesehatan dan pendikan, program bantuan komplementer sedangkan dalam Pasal 7 menyebutkan bahwa kewajiban yang harus dijalankan adalah pemunuhan komitmen sesuai dengan komponen masing-masing. Komponen kesehatan berupa berkunjung pada pusat-pusat kesehatan, komponen pendidikan dengan berupa mendaftarkan anak pada lembaga pendidikan dengan kehadiran minimal 85 persen.

Program bantuan tunai bersyaratberkomitmen dalam mengurangi stunting dimana dalam kewajibannya setiap peserta penerima bantuan diwajibkan untuk memanfaatkan pelayanan kesehatan terhadap anak dengan begitu perkembangan anak akan terpantau dengan baik oleh Pemerintah.program bantuan tunai bersyarat di Kabupaten Sumenep terlaksana dengan baik hal ini dapat dibuktikan dengan adanya penurunan angka stunting di Kabupaten Sumenep. salah satu respon cepat Pemerintah Kabupaten Sumenep dalam rangka menyukseskan program pencegahan stunting telah membuat regulasi, diantaranya Peraturan Bupati Nomor 14 Tahun 2019 tentang Percepatan Penanggulangan Stunting. Berdasarkan data Prevalensi Stunting di Kabupaten Sumenep, terjadi penurunan 18,2 persen dari tahun 2013 sebesar 52,5 persen, dan pada tahun 2018 menjadi 34,3 persen. (http://www.sumenepkab.go.id/berita/bac a/pemkab-sumenep-berhasil-turunkanangka-penderita-stunting)

Kesuksesan program memerangi dan menurunkan angka penderita stunting itu tidak lepas dari kerja sama semua pihak, serta dukungan segenap lapisan masyarakat untuk menggalakkan pencegahan stunting. Penurunan angka stunting ini juga melibatkan program bantuan tunai bersyaratyang memberikan sisi positif dalam memberikan pendampingan dan pelayanan kesehatan terhadap Ibu Hamil Kurang Energi Kronis (KEK), anak dibawah dua tahun dan Balita. Dalam pendampingannya program bantuan tunai bersyaratjuga berkomitmen dalam penanganan stunting dimana menurut survei microsave consulting Indonesia (2019) menyatakan bahwa 97\% keluarga penerima manfaat memeriksakan kehamilan di puskesmas, 48\% keluarga penerima manfaat menggunakan alat $\mathrm{kb}$, 94\% rutin memeriksakan bayi ke pusat kesehatan, 81\% keluarga penerima manfaat memberikan asi eklusif pada bayi, $52 \%$ anak 
keluarga penerima manfaat mendapatkan vitamin a, 71\% anak program bantuan sosial tunai bersyarat mendapatkan imunisasi lengkap, 85\% anak usia 1-5 tahun rutin melakukan pemeriksaan, 63\% anak usia 5-6 tahun rutin melakukan pemeriksaan, $88 \%$ keluarga penerima manfaat telah memiliki kartu BPJS mencangkup seluruh anggota keluarga.

Data tersebut membuktikan bahwa program bantuan tunai bersyaratmampu menekan angka stunting, akan tetapi tidak dapat dipungkiri bahwa bantuan uang yang diberikan kepada masyarakat dapat dikatakan dibelanjakan tidak sesuai dengan kebutuhan anak oleh sebab itu dihimbau agar dipergunakan sebagai mana mestinya Seperti yang diketahui bahwa bantuan uang yang diberikan oleh Pemerintah dapat dibelanjakan dengan kebutuhan anak misalnya dibelanjakan makanan bergizi yang baik untuk tumbuh kembang anak. Hal tersebut terjadi akibat kurangnya informasi dan pengetahuan masyarakat akan bahaya Stunting pada anak, sehingga kebutuhan yang seharusnya untuk keperluan anak dipergunakan untuk keperluan yang lain, oleh sebab itu dibutuhkan edukasi untuk masyarakat akan pentingnya menjaga pola asuh dan gizi pada anak.

Begitupun juga untuk Kabupaten Sumenep sebagian besar penerima manfaat bantuan Program bantuan tunai bersyaratkurang memahami akan pentingnya menjaga pola asuh dan gizi anak, meskipun angka Stunting mengalami penurunan akan tetapi tidak dapat dipungkiri bahwa pemikiran masyarakat terhadap gizi anak masih rendah. Oleh sebab itu dibutuhkan edukasi yang memberikan informasi terkait dengan Stunting dengan memperhatikan konsumsi yang diberikan kepada anak.

Untuk memberikan edukasi dan informasi terkait Stunting pada anak maka dibutuhkan sosialisasi dan interaksi aktif untuk mencegah Stunting pada anak dengan melibatkan masyarakat Kampung polay Kecamatan Gapura khususnya untuk penerima bantuan Program bantuan sosial tunai bersyarat. Perlu kita pahami bersama bahwa pemberian edukasi dan pengetahuan dasar mengenai Stunting yang diberikan akan mampu untuk mengubah pola pikir dan perilaku masyarakat yang menyangkut dengan pemberian Gizi pada anak dengan memberikan makanan yang bergizi.

\section{METODE DAN PELAKSANAAN}

\section{Metode}

Pengabdian masyarakat ini menggunakan metode penelitian kualitatif untuk menentukan cara mencari, mengumpulkan, mengolah dan menganalisis data hasil pengabdian. Metode penelitian kualitatif dapat digunakan untuk memahami interaksi sosial, dimana menurut Moleong (2007:6) adalah 
penelitian yang bermaksud untuk memahami fenomena tentang apa yang dialami oleh subjek penelitian misalnya perilaku, persepsi, motivasi,tindakan, dll., secara holistik, dan dengan cara deskripsi dalam bentuk kata-kata dan bahasa, pada suatu konteks khusus yang alamiah dan dengan memanfaatkan berbagai metode alamiah. Sedangkan menurut Koentjaraningrat (1993:83) penelitian kualitatif terdiri dari tiga model, yaitu format deskriptif, format verifikasi, dan format grounded research. Dalam pengabdian ini digunakan metode kualitatif dengan desain deskriptif, yaitu penelitian yang memberi gambaran secara cermat mengenai individu atau kelompok tertentu tentang keadaan dan gejala yang terjadi. Sehingga secara umum penelitian kualitatif bertujuan memperoleh gambaran seutuhnya mengenai suatu hal menurut pandangan manusia yang diteliti.

Metode pelaksanaan kegiatan dalam pengabdian masyarakat dalam rangka menambah pengetahuan masyarakat mengenai pencegahan stunting bagi anak dengan menggunakan beberapa metode.

1. Pemberian edukasi dan informasi yang dilakuan melibatkan masyarakat penerima bantuan sosial dengan memberikan penjelasan melalui sosialisasi dan menggunakan media visualiasi dengan intrumen alat berupa Laptop, infokus, layar putih dan pembagian selebaran sebagai bahan bacaan bagi masyarakat mengenai penyakit Stunting dan macam-macam bantuan dalam mendukung stunting.

2. Komunikasi interaktif, dimana tim pengabdian kepada masyarakat membuka ruang komunikasi interaktif dengan mitra kerja untuk saling sharing mengenai kendala yang dihadapi dalam keluarga khususnya kendala bagi pertumbuhan anak.

3. Metode pembelajaran dan edukasi yang dipergunakan dalam pengabdian masyarakat ini bervariasi, dengan ceramah, tukar pendapat, diskusi, dan simulasi. Adapun alokasi waktu dari edukasi ini selama 50 menit.

\section{Pelaksanaan Kegiatan}

Rangkaian kegiatan yang dilakukan untuk program pengabdian pada masyarakat sebagai berikut:

1. Perencanaan

Pemberian edukasi dan informasi terkait dengan pencegahan stunting kepada masyarakat penerima bantuan khususnya bantuan Program bantuan tunai bersyaratatau bantuan tunai lainnya akan dibagi menjadi dua sesi. Sesi pertama bertujuan Untuk memberikan 
pemahaman Tentang bahaya stunting dan pencegahan stunting sedangkan untuk sesi kedua akan dibahas mengenai pentingnya menjaga pola asuh dan pemberian makanan bergizi bagi anak. Sesi pertama terdiri dari 6 bagian dengan alokasi Waktu 50 menit, yaitu:

1. Sesi pertama, akan memberikan memahaman tentang Stunting, tujuan dalam bahasan ini yaitu untuk memberikan gambaran dan informasi kepada kelompok masyarakat penerima bantuan mengenai bahaya stunting, dalam sesi pertama ini membutuhkan waktu sekitar 25 menit dengan menggunakan metode pembelajaran ceramah, diskusi dan simulasi. cakupan bahasan yang akan dibahas dalam sesi pertama ini yaitu :
a) Pengertian
mengenai Stunting
b) Ciri-ciri dan bahaya stunting
c) Gejala dan akibat stunting
d) Pencegahan stunting bagi anak

2. Sesi kedua, akan memberikan pemahaman tentang Pemenuhan Gizi Anak Usia Dini dan Ibu serta memanfaatan bantuan sosial yang diberikan oleh pemerintah untuk mencegah stunting. Setelah pembelajaran modul ini diharapkan peserta mampu memanfaatkan bantuan sosial untuk pemenuhan gizi bagi anak usia dinidan ibu hamil untuk pencegahan stunting. Sama halnya dengan sesi pertama, sesi kedua membutuhkan waktu sekitar 25 menit dengan menggunakan metode pembelajaran ceramah, diskusi dan simulasi dengan membahas:

a) Bantuan sosial

b) Bahan pangan yang ada di lingkungan sekitar rumah

c) Pengolahan bahan pangan untuk memenuhi gizi seimbang.

\section{Kerjasama}

Pengabdian ini melibatkan beberapa mitra dalam upaya kerjasama mensukseskan pengadian kepada masyarakat ini seperti Ketua kelompok Polay dan Kelompok masyarakat penerima bantuan khususnya Program bantuan sosial tunai bersyarat.

Tabel 1. Daftar kelompok mitra

\begin{tabular}{|l|l|l|l|}
\hline $\begin{array}{l}\text { N } \\
\mathbf{o}\end{array}$ & $\begin{array}{l}\text { Kelompo } \\
\text { kenis }\end{array}$ & $\begin{array}{l}\text { Jumlah } \\
\text { Kelamin } \\
\text { angot }\end{array}$ \\
\hline 1. & Polay Deje & $\begin{array}{l}\text { Perempua } \\
\mathrm{n}\end{array}$ & $\begin{array}{l}22 \\
\text { Orang }\end{array}$ \\
\hline
\end{tabular}




\begin{tabular}{|l|l|l|l|}
\hline 2 & Polay Laok & $\begin{array}{l}\text { Perempua } \\
\mathrm{n}\end{array}$ & $\begin{array}{l}\mathbf{2 5} \\
\text { Orang }\end{array}$ \\
\hline
\end{tabular}

3. Publikasi melalui media

Program yang dilaksanakan, kemudian dipublikasikan melalui jurnal pengabdian masyarakat

\section{Pelaporan Akhir}

Laporan akhir merupakan laporan dari seluruh rangkaian kegiatan sebagai wujud pertanggungjawaban secara administratif dari tim pelaksana kepada LPPM Universitas Wiraraja. Kegiatan membutuhkan waktu selama enam bulan.

\section{HASIL DAN PEMBAHASAN}

\section{Hasil}

Salah satu upaya pencegahan stunting yang dilakukan Kementerian Sosial yaitu dengan memberikan bantuan sosial tunai yang bertujuan untuk pemenuhan kebutuhan sehari-hari Keluarga Penerima Manfaat. Namun kecenderungannya penggunaan bansos belum sesuai dengan tujuan yang diharapkan. Peran sumber daya manusia Kesejahteraan Sosial dalam Pemanfaatan Bantuan Sosial Untuk Pemenuhan Gizi Bagi Anak Usia Dini dan Ibu Hamil adalah sebagai edukator, motivator dan mobilisator untuk membantu keluarga penerima manfaat memanfaatkan bantuan sosial sesuai dengan tujuannya.

Terkait pencegahan dan penanganan stunting, sumber daya manusia Kesos mempunyai peran sebagai pendidik, fasilitator, penyuluh sosial, dan mobilisator. Kegiatan dilakukan melalui pemberian informasi, sosialisasi, memfasilitasi dan menggerakkan keluarga serta masyarakat agar mendukung pemenuhan kebutuhan, peningkatan kesadaran dan membangun komitmen untuk perubahan perilaku. Hasil kegiatan Edukasi Pencegahan Stunting Bagi Keluarga Penerima Manfaat Bantuan Sosial Kampung Polay Kecamatan Gapura memiliki respon yang positif pada saat dilakukannya edukasi pencegahan stunting, beberapa masyarakat antusias terhadap kegiatan pemeberian pemahaman mengenai isu stunting yang diberikan sehingga edukasi yang dilakukan berjalan dengan maksimal. Kelancaran program pengabdian kepada masyarakat ini tentunya didukung oleh masyarakat penerima bantuan sosial yang memiliki minat dan ketertarikan terhadap permasalahan stunting dan pola asuh anak yang baik.

\section{Pembahasan}

Pelaksanaan kegiatan pengabdian ini ditemukan kendala terkait dengan penyampaian bahasa yang dirasa kurang maksimal dilakukan, hal ini disebabkan masyarakat kurang memahami dan menanggapi yang disampaika oleh tim pengabdian masyarakat sehingga untuk menimalisisr hal tersebut kami tim pengabdian berusaha untuk memberikan pemahaman sesuai dengan kemampuan 
dipahami oleh masyarakat penerima bantuan sosial. Selain itu minimnya pengetahuan masyarakat mengenai pola asuh anak menjadi kendala dalam pencegahan stunting, masyarakat menganggap kurang gizi pada anak bukanlah masalah yang besar sehingga mereka kurang memperdulikan kondisi yang terjadi pada anak. Mereka menganggap yang penting anak bisa makan tanpa memikirkan gizi yang cukup untuk anak. Pola pikir yang demikian menjadi ancaman dalam menigkatkan jumlah stunting yang ada dimasyarakat sehingga dibutuhkan pendampingan bagi masyarakat untuk menunjukkan perubahan perilaku didalam kehidupan masyarakat.

Perubahan pola pikir yang berdampak terhadap perubahan sikap dan perilaku masyarakat tidak mudah untuk dilakukan sehingga untuk menyelesaikan masalah ini tidak hanya sebatas dalam pemberian edukasi saja, tahapan berikutnya untuk terus mendukung perubahan masyarakat yang lebih baik dibutuhkan program dan kegiatan yang berkelanjutan begitupun juga untuk tim pengandian masyarakat diharapkan mampu untuk memberikan pengabdian yang berkelanjutan yang mampu untuk memberikan pandangan baru kepada masyarakat penerima bantuan mengenai pencegahan stunting. Selain menjadi kendala utama dalam edukasi pencegahan stunting kendala-kendala lain yang dihadapi oleh tim pengabdian masyarakat yaitu terkait dengan jadwal pertemuan yang dirasa cukup sulit untuk berkumpul disuatu tempat sehingga untuk mengumpulkan beberapa masyarakat membutuhkan waktu untuk menunggu kehadiran masyarakat menerima bantuan.

Edukasi pencegahan stunting untuk penerima bantuan sosial kampung polay melalui beberapa tahapan seperti ceramah atau sosialisasi mengenai stunting dengan memberikan rangkuman bacaan menganai penyakit stunting bagi anak selain itu ada media diskusi yang disediakan untuk menampung tanggapa dan pemikiran dari ibu rumah tangga penerima manfaat bantuan sosial. Pada pelaksanaan edukasi ini tim pengabdian masyarakat melakukan kerjasama dan koordinasi dengan Pemerintah Desa Kampung Polay Kecamatan Gapura untuk mengundang ibuibu yang mendapatkan bantuan sosial kedalam forum pertemuan yang dilakukan oleh tim pengabdia masyarakat.

Kerjasama dilakukan sebagai langkah pertama untuk lebih dekat dengan masyarakat setempat dan mengetahui problem yang dihadapi masyarakat khususnya ibu rumah tangga dalam menjaga pola asuh anak agar terhindar dari penyakit stunting. Dari kerjasama tersebut dalam pertemuan ibu-ibu rumah tangga yang tergolong dalam penerima manfaat 
bantuan sosial yang diberikan oleh Pemerintah dilakukan perkenalan terkait tujuan dari pengabdian masyarakat. Interaksi dengan ibu rumah tangga berlanjut hingga sharing knowledge terkait pentingnya pola asuh anak yang dilakukan selama ini sehingga di temukan beberapa pokok masalah yang menjadi alasan dari masyarakat. Beberapa problem tersebut adalah;

1. Faktor budaya dan mindset masyarakat yang masih rendah. Pola pikir masyarakat kampung polay yang masih rendah dimana masyarakat menganggap penyakit stunting pada anak bukanlah penyakit yang serius yang harus dicemaskan, mereka berfikir selama memberikan makanan kepada anak dan tidak kelaparan hal itu sudah cukup untuk dilakukan. Pola pikir yang seperti ini menjadi masalah terbesar dalam masyarakat untuk itu dibutuhkan sosialisasi yang berlanjut sebagai tindakan untuk mengantisipasi meningkatnya stunting bagi anak.

2. Pemanfaatan bantuan yang diberikan oleh Pemerintah tidak dikontol dan dimanfaatkan dengan baik, sehingga masyarakat melupakan tujuan dan maksud diberikannya bantuan tersebut. Bantuan yang diberikan belum dibelanjakan sebagaimana mestinya dengan memenuhi belanja makanan yang bergizi bagi anak.

3. Rendahnya pengetahuan mengenai penyakit stunting bagi anak, hal ini disebabkan kurangnya informasi yang didapatkan oleh masyarakat.

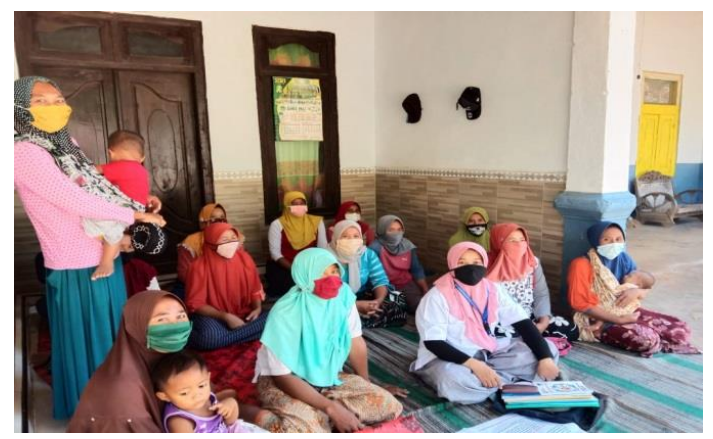

Gambar 1. Dokumentasi Kegiatan Edukasi Stunting di Kampung Polay Laok

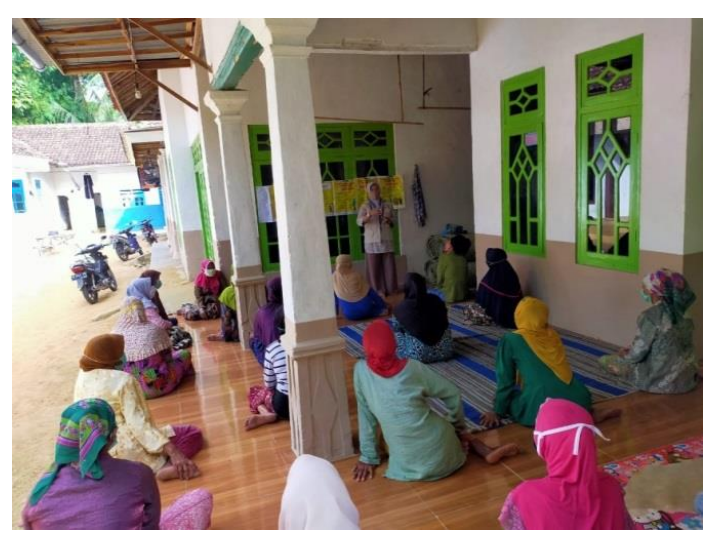

Gambar2. Dokumentasi Kegiatan Edukasi

Stunting di Kampung Polay Laok

Ketika kita mengetahui permasalahan masyarakat, tim pengabdian masyarakat melakukan edukasi tentang stunting terhadap masyarakat khususnya ibu-ibu rumah tangga yang menerima bantuan sosial, tidak hanya memberikn informasi akan tetapi melakukan simulasi bagaimana cara agar gizi anak terpenuhi dengan menyiapkan makanan yang bergizi pada anak. Selain itu, memberitahukan bahwa 
memperhatikan tumbuh kembang anak sangatlah penting oleh sebab itu tim penelitian melakukan interaksi secara mendalam terhadap ibu rumah tangga yang mengalami kesulitan dalam mengasuh anak, dengan melakukan interaksi ini memberikan kesempatan bagi tim pengabdian untuk ikut serta dalam menyelesaikan masalah yang dihadapi ibu rumah tangga yang hadir dalam pertemuan tersebut.

Terkait dengan permasalahan gizi anak dimana ibu rumah tangga belum mengetahui apa saja yang harus dilakukan untuk mencukupi kebtuhan gizi pada anak maka tim pengabdian juga ikut menjelaskan makanan-makanan yang baik untuk pertumbuhan anak yang dapat mencegah penyakit Stunting.

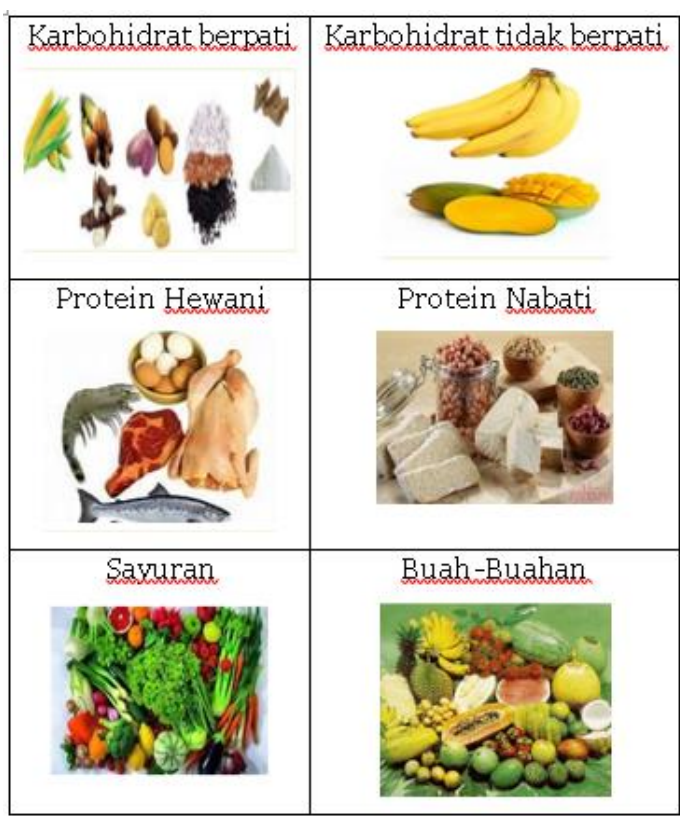

Gambar 3. Zat Gizi pada makanan

\section{Isi Piringku}

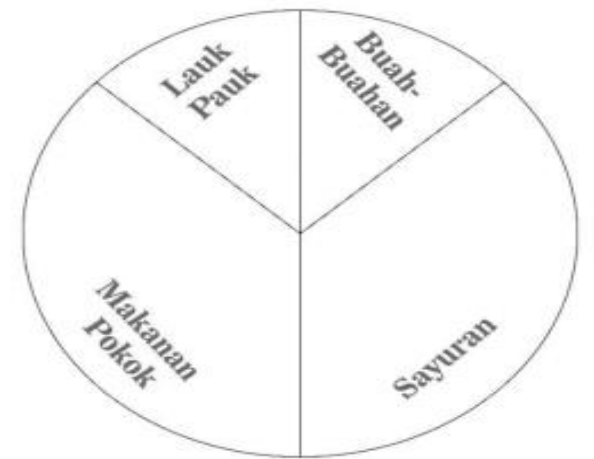

Gambar 4. Bahan Pangan Bergizi di sekitar rumah

Sumber: Modul 6 Pemanfaatan bansos untuk pemenuhan gizi (Tanoto Foundation)

Selain itu juga kami juga ikut membina ibu rumah tangga agar mampu membelanjakan bantuan sosial yang didapatkan untuk memenuhi kebutuhan pokok bagi keluarganya. Karena pengabdian masyarakat ini bersifat sosialisasi, maka alat perantara yang digunakan selama melakukan kegiatan adalah buku, tape recorder, dan alat tulis. Buku yang digunakan adalah buku yang berhubungan dengan stunting. Tape recorder digunakan untuk merekam interaksi tanya jawab yang dilakukan tim pengabdian dengan masyarakat setempat, sedangkan buku tulis dan pulpen berfungsi untuk mencatat hal-hal apa yang menjadi point penting selama interaksi. 


\section{PESAN UMUM GIZI SEIMBANG}

1. Mari kita bersyukur kepada Tuhan $\mathrm{YME}$, karena Indonesia memiliki ragam makanan yang dapat kita nikmati bersama.

2. Perbanyak makan sayuran dan cukup buahbuahan

3. Biasakan mengkonsumsi lauk pauk yang mengandung protein tinggi

4. Biasakan mengonsumsi aneka ragam makanan pokok.

5. Batasi konsumsi pangan manis, asin dan berlemak abetes dan serangan jantung.

6. Biasakan Sarapan /makan pagi.

7. Biasakan minum air putih minimal 8 gelas

8. Biasakan membaca label pada kemasan pangan

9. Cuci tangan pakai sabun dan air bersih mengalir.

10. Lakukan Aktivitas fisik selama $\mathbf{3 0}$ menit dalam sehari.

Gambar 5. Penuhi Gizi seimbang

\section{PENUTUP}

\section{Simpulan}

Pelaksanaan program kegiatan pengabdian kepada masyarakat berupa edukasi pencegahan stunting bagi keluarga penerima manfaat bansos kampung polay Kecamatan Gapura Kabupaten Sumenep pada dasarnya berusaha untuk memberikan pengetahuan dan tambahan wawasan bagi masyarakat khususnya bagi ibu rumah tangga agar memahami bahaya penyakit stunting serta lebih memperhatikan kembali pola asuh pada anak dengan memperhatikan makanan dan perkembangan yang terjadi pada anak.

\section{Saran}

Kurangnya informasi mengenai Stunting memberikan dampak buruk terhadap perkembangan dan pola asuh anak sehingga perlu diadakan memantauan dan edukasi lanjutan bagi penerima manfaat bantuan social.

\section{UCAPAN TERIMA KASIH}

Terimakasih kepada tim pengabdian mandiri dan masyarakat penerima bantuan sosial Kampung Polay yang telah melakukan pengabdian dan ikut serta dalam partisipasi edukasi sehingga dapat berjalan dengan baik dan lancar, serta kepada Fakultas Ilmu Sosial dan Ilmu Politik Universitas Wiraraja dalam memberikan fasilitas kelengkapan dokumen yang dibutuhkan selama pelaksanaan pengabdian ini berlangsung.

\section{DAFTAR PUSTAKA}

Arikunto, S., Prosedur PENGABDIAN MASYARAKAT : Suatu Pendekatan Praktik. (Edisi Revisi). Jakarta : Rineka Cipta, 2010.

Dunn, William N. 2000. Pengantar Analisis Kebijakan Publik. Yogyakarta:Gadjah Mada University Press.

Keban, Yeremias T. 2014. Enam Dimensi Strategis Administrasi Publik. Konsep, Teori dan Isu. Yogyakarta : Gava Media

Koentjaraningrat, Metode-Metode PENGABDIAN MASYARAKAT 
Masyarakat, Edisi Ketiga, Jakarta: Gramedia, 1993.

Mardikanto, Totok \& Soebianto, Poerwoko. 2013. Pemberdayaan Masyarakat dalam Perspektif Kebijakan Publik. Bandung : CV Alfabeta

Moleong, Lexy J., Metodologi PENGABDIAN MASYARAKAT Kualitatif, Bandung : PT Remaja Rosdakarya, 2007.

Nawawi, Hadari, 2011. Manajemen Sumber Daya Manusia. Gadjah Mada University Press : Yogyakarta.

Peraturan Menteri Sosial RI nomor 1 Tahun 2018 Tentang Program bantuan sosial tunai bersyarat.

Sulistiyani, Ambar Teguh, 2017. Kemitraan dan Model-Model Pemberdayaan. Yogyakarta : Gava Media

Suparjan, Hempri Suyatno. 2003. Pengembangan Masyarakat dari Pembangunan sampai Pemberdayaan. Yogyakarta : Aditya Media

"Pemkab Sumenep Berhasil Turunkan Angka Pnderita Stunting”,Dalam Situs Http://Www.Sumenepkab.Go.Id "Angka Stunting Di Indonesia Masih Lebih Tinggi Dari Toleransi Who", Dalam Situs Https://Mediaindonesia.Com Buku Pedoman Kementrian Sosial RI Modul 1, "Pencegahan dan Penanganan Stunting Bagi SUMBER DAYA
MANUSIA KeSos”, Tanoto Foundation.

Buku Pedoman Kementrian Sosial RI Modul 2, "Permasalahan Stunting", Tanoto Foundation.

Buku Pedoman Kementrian Sosial RI Modul 6, "Pemanfaatan Bantuan Sosial dalam Pemenuhan Gizi”, Tanoto Foundation.

Buku Pedoman Kementrian Sosial RI, "Pedoman TOT Stunting", Tanoto Foundation. 